\title{
MIÉRT NINCS MAGYARORSZÁGON PEDAGÓGIA DOKTORI (ED.D.) FOKOZAT?
}

\author{
BÁRDOS JENÖ \\ az Eszterházy Károly Főiskola Tanárképzési és Tudástechnológiai Karának \\ egyetemi tanára \\ bardos.jenoistvan@chello.hu
}

\begin{abstract}
A közelmúlt magyar doktori fokozatainak bemutatását követöen a szerző ismerteti a Magyarországon ismeretlen, de Angliában és az Egyesült Államokban egyre népszerübb, a Ph.D.-val egyenértékünek elfogadott Ed.D. (Educationis Doctor) tudományos fokozat lényeges vonásait. Feltételezhetö, hogy a Magyarországon megvédett több mint 500 neveléstudományi doktori dolgozat jelentös része inkább a Pedagógia Doktora fokozat kritériumainak felel meg. A profiltisztitás érdekében célszerü Pedagógiai Doktori Iskolákat létrehozni, akár önállóan, akár már müködö Ph.D. Doktori Iskolák keretein belül. Az oktatás és nevelés, a nevelésügyi menedzsment és minöségbiztositás világában számos olyan célcsoport létezik, amelynek jelöltjei fokozatszerzésükkel nem csak megkönnyitenék saját karrier-lehetöségeiket és az emberi eröforrás-gazdálkodást, hanem jelentös mértékben növelhetnék a tudományos kutatás minöségét és tekintélyét a pedagógia világának minden területén.
\end{abstract}

\section{Kezdetben vala...}

Több mint másfél évtizede élünk az úgynevezett „tanított” Ph.D.-k világában, ami azt jelenti, hogy a jelölt (doktorandusz) több tanár által tartott kurzuson, több kutató irányításával, témavezetővel beszámolókon, konferenciákon és publikációkban csiszolódva, egy jól „megcsinált” disszertációval éri el fokozatát. A korábbi évtizedek - amelyeket laikus általánosítással „self-made-man” korszaknak is nevezhetnénk - jótékony homályba burkolóznak, hiszen különleges elszántság kellett ahhoz, hogy egy alacsony technikai fejlettség közegéböl (számítógép helyett írógép, világháló helyett könyvtárakba és helyszínekre utazgatás, a szakmai kapcsolatteremtés nehézségei stb.) valaki mégis kiemelkedjen, időt és pénzt nem kímélve szellemi elismertséget szerezzen, fokozathoz jusson. Milyen grádicsokról volt szó?

A huszadik század jellegzetes képződménye, a bölcsészettudomány doktora cím (közismertebben „kisdoktor”), a világháború után is élő jelenség volt, mint a szovjet mintára bevezetett kandidatúra előzménye: lépcsőfok a diploma után, kandidatúra előtt. Nem tekintették ,igazi” tudományos fokozatnak (bár vizsgákkal és a disszertáció nyilvános védésével járt együtt), pedig csak ez maradt az egyete- 
mek kezében. Arra azért elegendő volt, hogy adjunktusi kinevezést lehetett rá kapni a magyar egyetemeken és föiskolákon, és a bölcsészdoktor is viselhette neve elött a dr. rövidítést. Ugyanakkor az egyetemek komolyan vették ezt a feladatukat, olyannyira, hogy amikor a 90-es években megszünt ez a cím a Ph.D. fokozatok és az új doktori iskolák megjelenésével, lehetővé tették - némi korlátozással (summa cum laude) - e címek átminősítését Ph.D. fokozattá. A bölcsészdoktori cím elnyerésének lehetösége tehát megszünt, ami hatalmas ürt hagyott maga után, ugyanis így a diploma és a Ph.D. között semmilyen, szakmailag elismert kiemelkedési lehetöség nem maradt. A beindult doktori iskolák és védések magas színvonala, másfelöl a tanári hivatás küzdelmesebbé válása egyre távolabb sodorta a mindennapi tanárságtól a tudományos fokozat megvédésének lehetőségét. Valójában a felsőoktatási és közoktatási életformák is eltávolodtak egymástól, a tudományosság igénye kifakult, elhervadt és el is tünt az iskolák többségéből, s véle a tudós tanárok is.

A szovjet mintára bevezetett kandidátusi fokozat (vagyis a jelölt, aki majd akadémiai doktor lesz) nem az egyetemek által adott fokozat volt, az MTA-hoz tartozott, bár a vizsgák bizottsági tagjai az egyetemi világ jeles képviselői voltak. Vizsgákkal és publikációs tevékenységgel „kívülről” is megközelíthető volt ez a fokozat, de előnyösebb helyzetben voltak azok, akik tudományos ösztöndíjban részesültek. Ezt követhette az MTA doktora fokozat, amely a „nagydoktor” szóval vált köznyelvivé. A kandidátus fokozat voltaképpen a Ph.D.-nak feleltethető meg. (A középkorban az egyetemi doktorátus, ha nem teológiai vagy orvostudományi volt, akkor csakis filozófiai lehetett: innen ered a Ph.D. [filozófia doktora] ma már más tudományágakra is átsugárzó, metaforikus jelentése. Eredetileg azt is jelentette, hogy valaki a tudományát akárhol előadhatta: ius ubique docendi.) Mivel a nyugati világban a Ph.D. az egyetlen igazán elismert tudományos „,végfokozat”, ez az itthoni első tudományos fokozat (a Ph.D.) elveszítette azt a jelentését, hogy vigyázz, még csak jelölt vagy, tudós kutatóként el kell nyerned az MTA doktora címet is! Szívszorítóan dermesztő adat, hogy a neveléstudományokban a több mint ötszáz minősített között mindössze harminc (!) nagydoktor akad, és még ez a piciny szám is drasztikusan csökkenne, ha kivonnánk belőle a hetven év felettieket. Milyen okai lehetnek ennek?

\section{Fokozatok a neveléstudományban}

Miközben a nevelés/oktatás világa globális mértékben rendkívül összetetté, mondhatni kaotikussá vált, azért fókuszpontjait megőrizte az elmélet - gyakorlat - megvalósíthatóság háromszögében (amely óhatatlanul felidézi Arisztotelész epistemephronesis-techne fogalom-triászát). Főként az angolszász országok neveléstudományi fokozatainak alakulásában érhető tetten, hogy utánozván más szakmák (jogász, orvos) „céhes” jogait, igény támadt olyan tudományos fokozatokra, amelyek nemcsak az egyetemek világából érhetők el. Így a Ph.D.-n túlmenően (amely inkább az 
„elméleté”), létrejött egy Ed.D. fokozat is (amely inkább a „gyakorlaté”). A reformok jegyében - mivel a Ph.D. és az Ed.D. már úgy összefonódott - felmerült egy P.P.D. (Professional Practice Doctorate) bevezetésének lehetősége is (Schulman et al., 2006), amely az oktatási közigazgatásban, szervezésben, minőségbiztosításban részt vevők számára biztosítana tudományos fokozatot. Mivel bennünket jelenleg leginkább a Pedagógia Doktorának magyarított Ed.D. érdekel, az elkövetkezendőkben ezzel foglalkozunk.

\section{Ed.D. - a Pedagógia Doktora}

A Pedagógia Doktora fokozat (angolul: Doctor of Education, Ed.D., illetve latinul: Educationis Doctor) közismert neveléstudományi tudományos fokozat föként az angolszász országokban. A több mint százéves Neveléstudomány Doktora (Ph.D. in Education) tudományos fokozat „köpönyegéből bújt elö”, alapítása az Egyesült Államokban a múlt század húszas éveire nyúlik vissza (lásd Harvard University, 1920). A Pedagógia Doktora fokozat Angliában a 90-es évek végén kezdett elterjedni (29 egyetem), amikorra világossá vált, hogy az inter-, multi- és transz-diszciplináris neveléstudományokban célszerü különbséget tenni a neveléstudomány elméleteit továbbfejlesztő, bonyolult kutatási metodikájú neveléstudományi Ph.D.-k és a közoktatás és a felsőoktatás gyakorlatából kinövő, a pedagógiai innovációt célba vevő, elsősorban tantárgy-pedagógiai kutatások között (Ed.D.). Vannak olyan felsőoktatási intézmények, amelyek csak a Pedagógia Doktora tudományos cím elérése céljából indítanak doktori iskolákat (Harvard University) és vannak olyanok is, amelyek csak Neveléstudományi Ph.D. fokozatokat adnak ki (McGill University, Stanford University). Természetesen olyan is előfordul, hogy ugyanaz az intézmény mindkét fokozatot kiadja (Universities of Alberta, Calgary, Toronto - Kanadában). Előfordul, hogy még maguk az Ed.D.-k is tovább specializálódnak, például tehetségek nevelése, egészséges életmód stb. (Ed.D. in Gifted Education: University of Virginia, Curry School of Education; Ed.D. in Health Education: University of Texas at Austin, College of Education). A Harvard Egyetem (Cambridge, MA) intézete (Graduate School of Education) oktatásügyi vezetők részére hirdet Pedagógia Doktora fokozatot (Doctor of Educational Leadership). A Minnesota-i Egyetem oktatáspolitika, nevelésügyi államigazgatás és humán erőforrás gazdálkodásban hirdet témákat Ed.D fokozat megszerzésére. A továbbiakban a minnesotai program szövegéből idézünk: ,a felvételi eljárás színvonala, menete, valamint a tanulmányi munka a Ph.D. kurzusokhoz hasonló. A program nagyobb részét nappalin kell elvégezni, ami azt jelenti, hogy legalább egy tanévet az egyetemen kell tölteni a teljes program második felében. A vizsgákra vonatkozó szabályok és eljárások, a jelöltség, a határidők, a bizottságok kijelölése, a disszertáció benyújtásának feltételeire vonatkozó szabályok azonosak a Ph.D.-vel." (University of Minnesota, University Catalogs, 2010). Hasonló szabályokat lehet találni a University of Washington 
(Seattle, WA) és a National Institute Of Education (NIE, Singapore) előírásaiban minthogy a földrajzi távolság a követelményeken nem változtat.

\section{A Ph.D. és az Ed.D fokozatok összehasonlítása}

Az Egyesült Államokban hivatalosan nincs különbség, az NSF (National Science Foundation) közel harminc olyan kutatáson alapuló fokozatot ismer el, amely a Ph.D.vel egyenértékü (például jog, üzleti tudományok, ipari formatervezés, zene, ipari technológiák, zenei nevelés, testnevelés, közigazgatás, természettudomány, sőt a modern nyelvek is!). Ezek egyike a Doctor of Education (Ed.D.) A Pedagógia Doktora fokozat megszerzéséhez vezető tanulmányok lebonyolításáért többnyire az egyetem/föiskola relatív önállósággal müködő intézete felel (College of Education, vagy [Postgraduate] School of Education).

A Pedagógiai Doktori Iskola - csakúgy mint más doktori iskolák - a kutatásra fókuszáló, tanított kurzusokból áll (vö.: taught Ph.D. courses), szemléletében azonban mégis különbözik a leginkább hasonló Neveléstudományi Doktori Iskoláktól. Elvárása az, hogy a kutatás - $\mathrm{s}$ véle a sikeresen megvédett disszertáció - a mindennapi gyakorlatban bizonyító, tényleges pedagógiai innovációt jelentsen (például a tantervek, tananyagok, mérésmetodikai megoldások, oktatástechnológiai eljárások, tanítási és tanulási stratégiák és alkalmazások stb. világában). E cél elérése érdekében igen széles körü szaktudományi alapozást nyújt az adott kontextus rokon- és kritikai tudományai körében; a kutatási módszereket nem csak egyéni, hanem kutatócsoportok együttmüködése formájában is müveli, fejleszti. Lehetőséget nyújt arra, hogy a doktori iskolában szerzett gyakorlat eredményeként (az „érés” következményeként) a jelöltek csak később válasszanak egyéni kutatási témát, amely tényleges müködési területükhöz tartozik és nem feltétlenül az adott doktori iskola preferált témája. Az alkalmazott tudományok kutatása éppúgy semmiféle engedményt nem tür a tudományos szigorúság tekintetében, mint az inkább elméleti beállítottságú kutatások, ugyanakkor szélesebb inter- és multidiszciplináris áttekintést igényel az oktatás, nevelés, kutatás közösséget szolgáló világában. Mindez nem zárja ki a specializációkat (például információs technológiák, anya- és idegen nyelvi képzések, tanárképzés, nevelésszociológia, tehetségkutatás, pedagóguskutatás stb.), de azok tágassága feltételül szabja az érintett rokon- és kritikai tudományok elmélyült tanulmányozását.

Magyarországon a demográfiai adatok zuhanása az adott korosztályban - ugyanakkor a felsőoktatás tömegesedése - nem termelt ki olyan elitet a friss diplomások között, akik megtölthetnék a Neveléstudományi Doktori Iskolák padsorait, és meg is felelnek a magas elvárásoknak. A már jelentős tapasztalattal rendelkező tantárgy-pedagógusok mint doktorjelöltek igen gyakran a szakdiszciplínákba menekülnek (például alkalmazott nyelvészet vagy természettudományi doktori iskolák), holott témáik, kutatásaik teljességgel a neveléstudomány világába tartoznak. Ha 
ezek a kutatások újfent a neveléstudományba kerülnének, az jelentősen megnövelné a neveléstudomány súlyát, tekintélyét (így például a nyelvpedagógus nem nyelvészeti, hanem pedagógiai doktorátust szerezne). A Neveléstudományi Doktori Iskolák most már számos olyan jelöltet iskoláznak be, akik a praxis világából érkeznek és így szereznek doktori fokozatot. Disszertációjuk lehet tipikusan Ed.D. jellegü, de ez nem válik nyilvánvalóvá, mivel nálunk ez a fokozat nem explicit. Sokan valóban „végfokozatnak” tekintik ezt a cselekményt, és egy kutatói szakasz után viszszatérnek az oktatás világába - a kutatói habitus nem válik állandóvá. Többek között, ez az egyik magyarázata annak, hogy miért van olyan kevés nagydoktor a neveléstudományban minősítettek között.

A Pedagógiai Doktori Iskolák (cél: az Ed.D. fokozat megszerzése) elsősorban a tényleges köz- és felsőoktatási tanári létből vagy az oktatási közigazgatásból fogadnak ambiciózus és már jelentős gyakorlattal rendelkező kollégákat. (A már meglévő doktori iskolák befogadhatják ezt az új fokozatot, ha erős a tanárképzésük és vannak megfelelő tanárképzési szakembereik - másutt meg kell alapítani a Pedagógiai Doktori Iskolát. Lehetővé válna a neveléstudományi doktori iskolák tematikai fókuszának profiltisztítása, az eredeti Ph.D karakterének megőrzése.

\section{Célcsoportok: oktatók az egyetemeken és a föiskolákon (elmélet és oktatói gyakorlat)}

Mind az egyetemi, mind a főiskolai tanárképzésben számos olyan - egyébként kiváló - oktatóval találkozhatunk, akik csak a szaktudományukat gazdagítják publikációikkal, az (alkalmazott) neveléstudományt nem. Így elvész az a tapasztalat, amely egyes intézményekben éppen a tanárképzés kiválóságához vezet. Az ilyen kiváló (nyelvész, biológus, informatikus stb.) oktatóknál elvárható lenne, hogy életpályájuk egy szakaszára a Pedagógia Doktora tudományos fokozatot is megszerezzék, amennyiben a tanárképzésnek kötelezték el magukat. A fokozat ismertté válása más szaktudományokban, nagyban növelné a neveléstudomány súlyát. Ez utóbbi érvünk tehát arról szólt, hogy a tanárképzésben elkötelezett, nem neveléstudományi szakemberek Pedagógia Doktora fokozatot is szerezzenek, ahogy a mérnöktanárnak is kell pedagógiai végzettséget szereznie.

\section{Célcsoportok: tanárok a közoktatásban: az életpályamodell (a praxis és az alkalmazott kutatások)}

Szorosan kapcsolódik a fenti címhez a mostanában formálódó tanári életpályamodell kívánatos progressziója és hierarchiája, amely a megnevezett, inkább életkorinak tủnő fokozatain át (kezdő, véglegesített, kiváló és mestertanár) a sztenderdek megadásával voltaképpen a tudós tanár e századi eszményképét kívánja megalkotni a jelen oktatási-nevelési környezetben. Éppen a megfelelö gyakorlati tapasztalat, a pedagógia 
„klinikumának” ismerete predesztinálná a kiváló és mestertanárok kutatásra is vállalkozó kisebbségét arra, hogy Pedagógiai Doktori Iskolába jelentkezzenek, ahol gyakorlatközeli absztrakcióikat elméleti és alkalmazott tudományos kutatásokkal alátámaszthatnák. (Elképzelhető, hogy idővel a Pedagógia Doktora fokozat megszerzése a mestertanárok kinevezésének egyik elvárt teljesítményévé válik.) Mivel kevés esélye van annak, hogy a közeljövőben a pedagógusi hivatás anyagi elismertsége növekedjen, meg kell teremteni a szellemi elismertség lehetőségét: erre a Pedagógia Doktora fokozat megszerzése vonzó kitörési irány lehet. Így felépíthető a tudós tanár huszonegyedik századi eszményképe: nekik kell megszüntetni az elmélet és gyakorlat közötti feszültségeket, és visszavezetni a tanári közösségeket a tényleges értelmiségi létbe. Ez az érvünk tehát $a$ tudós tanár tudományos és közéleti, $\mathrm{s}$ ez által társadalmi elismertségének egyik lehetőségéröl szólt, és a tanári életpályamodellbe illeszti a Pedagógia Doktora fokozat megszerzésének lehetőségét.

\section{Célcsoportok: oktatásügyi „,menedzserek” (megvalósíthatóság: igazgatás, gazdaság, adminisztráció)}

Manapság az iskolaigazgatók többsége a gazdasági kényszerek miatt inkább menedzser, sőt helyi politikus (grassroot-politics), még ha gyakran muszájból is. Tudományos képzettségük, neveléstudományi felkészültségük gyakran súlyos kívánnivalókat hagy maga után. Egy megfelelően felépített Pedagógia Doktori Iskola segíthetne rajtuk, akkor is, ha világuk az (államilag előírt) adminisztrációhoz, az igazgatáshoz, az oktatás-gazdaságtanhoz, minőségbiztosításhoz stb. kapcsolódik. Vissza kellene állítani az iskolaigazgatók tantestület előtti és külső tekintélyét, amire a Pedagógia Doktora cím elnyerése kiváló lehetőség lenne. (Elterjedésével kinevezési feltétellé is válhatna pl. a helyi önkormányzat politikai szeszélye helyett.) Ez az érvünk az iskolaigazgatók, oktatáspolitikusok stb. doktori továbbképzésének lehetőségéről szólt, amely egyben utat nyit a kutató iskolák megjelenése felé.

Jelenleg nincs régi értelemben vett szakfelügyeleti rendszer, a minőségbiztosítás pedig - bár nagy léptekben halad - még nem tekinthető megbízhatónak. Még a legbonyolultabb ipari értékelési rendszerekben is használják a személyi elbírálás, értékelés előnyeit. Egy ilyen pályán, ahol a neveltség voltaképpen mindig a humán tényezökön múlik, ki az a személy, aki - megfelelő tekintéllyel - érvelni, értékelni tud? A Pedagógia Doktora cím birtokosának tudása ide is illeszkedik. Érvelésünk tehát az oktatási rendszerek értékelését (pl. szakfelügyelök, akkreditációs bizottságok tagjai) szakirányú minősítettekre (és nem a vállalati életből idetévedt „hozzáértőkre”) bízná. 


\section{Kételyek, avagy vanitatum vanitas}

Természetesen az angolszász világban is megtörtént az, hogy a kétféle neveléstudományi fokozat együttélése, versengése nem kívánt mellékhatásokkal járt. Jóllehet többször leírták (Redden, 2007), hogy a Pedagógia Doktora jelöltjei másként közelítik meg a célt olyan intézményekben, ahol mindkét fokozatot ajánlják, elöfordul, hogy a Ph.D.-nak nagyobb tekintélye van. Ez a más megközelítés több együttmüködést kíván a jelöltektől, akik gyakran mások által begyüjtött adatbázisokat elemeznek és egyéni disszertációikat ugyanannak a problémának a különféle aspektusairól írják. A megírt munkák kombinációja így a tényleges probléma átfogó megoldását nyújtja. Ez valóban más megközelítés, mint az adatok (saját kezü) generálása, a tudományos hipotézis felállítása, tesztelése stb. A legerősebb Ed.D.ket erre specializálódott főiskolák/főiskolai karok ajánlják (például Vanderbilt, Peabody College, Nashville, Tenessee), amelyért - állítólag - érdemes több államon is átutazni. Másfelől, találtak olyan gyenge minőségü disszertációkat is (Levine, 2005), hogy rögvest az egész neveléstudományi doktori rendszer megújítását javasolták. Nincs tudomásom arról, hogy összehasonlító vizsgálatok folynának Magyarországon a már többször emlegetett több mint ötszáz neveléstudományi diszszertáció minőségéről vagy eljárásbeli karakterjegyeiről (bár kiváló kutatási téma), de valószínü, hogy itt is találhatnánk szintbéli vagy felfogásbeli különbségeket. (Saját akkreditációs munkáim során találkoztam olyan megvédett [nem neveléstudományi!] disszertációkkal, ahol a friss doktornak annyi szakmai publikációja sem volt összesen, amellyel egy jobb doktori iskolában abszolutóriumot kaphatna vagy szigorlatát engedélyeznék - mindez azonban más lapra tartozik). Meggyőződésem, hogy a Pedagógia Doktora fokozat bevezetése lehetőséget nyújtana arra, hogy a nevelés/oktatás világában élő vagy ehhez a területhez kapcsolódó szakemberek vonzó szellemi kitörési lehetöségekhez jussanak. Ugyanakkor jobban kitapinthatóvá válna, hogy a fokozatot szerzett kutató inkább az elmélet vagy inkább a gyakorlat, vagy inkább a kettő egybefonódott megvalósításának kiválósága-e.

\section{Pedagógiai Doktori Iskola indításának javasolt feltételei}

Az érveket tovább lehetne gyüjteni, de már az eddigiekből is látszik, hogy egy ilyen gyakorlatközeli Pedagógia Doktora fokozat át- meg átszövi, ugyanakkor integrálja az oktatás világának különféle szintjeit. Legnagyobb haszna azonban mégis az lehetne, hogy a tudományosság ismerete és tisztelete visszatérne az oktatás színtereire. Az összes ilyen kutatási eredmény a neveléstudományt gazdagíthatná. Ezért időszerünek tartjuk és javasoljuk Pedagógiai Doktori Iskola felállítását, a Pedagógia Doktora tudományos cím bevezetését.

A Pedagógia Doktora fokozatot olyan közoktatásban vagy felsőoktatásban, illetve a közigazgatásban legalább öt éve dolgozó mesterfokú diplomás nyerheti el, 
aki pedagógiai vagy neveléstudományi doktori iskolában legalább 15 kurzust abszolvált, abszolutóriumot szerzett, megfelel a minimális publikációs követelményeknek, doktori szigorlatot tett, illetve kutatáson alapuló doktori disszertációját megvédte.

Pedagógiai Doktori Iskola olyan egyetemen vagy föiskolán alapítható, amelynek (egyik) fó profilja a tanárképzés, legalább három kara van, és már rendelkezik doktori iskolával. A Pedagógiai Doktori Iskola törzstag oktatóinak és témavezetőinek kiválasztásában a minősitettség az alapvető feltétel, tagjai között azonban életkorra, (nemre, etnikumra, vallásra) történő hátrányos megkülönböztetés nem tehető. A Pedagógiai Doktori Iskola törzstagjainak létszáma minimum hét, maximum 12 fö, akiknek több mint fele habilitált, fóállású egyetemi tanár, illetve Professor Emeritus. A Pedagógiai Doktori iskola külső vagy belső témavezetője csak minősített lehet.

\section{Végül}

Félő, hogy a címben olvasható kérdésre igen kellemetlen válaszokat lehetne/kellene adni. A mélyben rejlö, valódi mozgató erő megnevezése azonban egyszerü: akarni kell! Félre az irigységgel, féltékenységgel, kishitüséggel, bizalmatlansággal! Ha a neveléstudományi szakma számára nem világos, hogy túl szük a merítési alap, hogy a doktori iskolákban túl kevés MTA doktora müködik, hogy jóval több interdiszciplináris felkészültségü, minősített pedagógiai szakemberre van szükség, hogy a több mint ötszáz minősítettnek a kutatói pályán is tevékenykednie kell, az nagy baj. A MAB által eszközölt bezárások és megszorítások már megkongatták a vészharangot. Elkelne a kormányzati segítség is: az elképzelés a tanári életpályamodellbe is beleillik. „Meddig alszol még...?”

\section{Irodalom}

Levine, A. (2005): Educating School Leaders. Education Schools Project. New York.

Poole, B. (2011): Notes on the emergence of Ed.D (Doctor of Education) programmes in the United Kingdom. Journal of the NUS Teaching Academy, 1 (1), 44-53.

Redden, E. (2007): Envisioning a New Ed.D. Inside Higher Education. http://www.insidehighered.com/news/2007/04/10

Shulman, L. S., Golde, C. M., Conklin, B. A., Garabedian, K. J. (2006): Reclaiming education doctorates: a critique and a proposal. Educational Researcher, Vol. 35 No. 3. 25-27.

University Catalogs, Doctor of Education (2010): University of Minnesota.

http//www.catalogs.umn.edu/grad/gen/edd.html letöltve: 2011. május 5. 